\title{
CONSTRAINTS ON SOUTH AFRICAN ENGLISH-AFRIKAANS INTRASENTENTIAL CODE SWITCHING: A MINIMALIST APPROACH
}

\author{
Ondene van Dulm, Stellenbosch University
}

\section{INTRODUCTION}

Since the 1970s, the phenomenon of code switching has been studied from a variety of theoretical perspectives. From a structuralist perspective, the most important question arising from this extensive study of code switching concerns the nature of the grammatical constraints on code switching. Many such constraints have been proposed, some of the more prominent of which will be discussed below. The main aim of this paper, however, is to provide the reader with an exposition of the Minimalist approach to code switching. Following the exposition of the Minimalist approach to code switching, a study in which the Minimalist assumption concerning the constraints on code switching is empirically evaluated with the aid of South African English-Afrikaans code switching data will be described. Finally, conclusions will be drawn regarding the theoretical and empirical validity of the Minimalist account of the constraints on code switching. As a starting point, however, it is essential to provide both a definition of the term "code switching" as it will be used in this paper, as well as a brief exposition of the differences between code switching and related phenomena such as borrowing, code mixing and interference.

\section{CODE SWITCHING AND RELATED PHENOMENA}

\subsection{Code switching}

The term "code switching" will refer here to "the alternate use of two (or more - OvD) languages within the same utterance or during the same conversation" (Hoffmann 1991:110). In this paper, the term "bilingual" will be used to refer to the notions of both 'bilingualism' and 'multilingualism', and anything that is said to apply to code switching between two languages should be taken to apply to code switching among more than two languages as well. In this 
paper, a switch will be indicated by the use of italics. There is no intention to imply that either the italicised or the non-italicised part of an utterance is in the dominant language. It is necessary to distinguish between three types of code switching, namely extra sentential code switching, intersentential code switching, and intrasentential code switching.

Extra sentential code switching involves the insertion of a tag from one language into an utterance entirely in the other language (Hamers \& Blanc 2000:259), as in (1).

(1) O nee hier's 'n paar goedjies, sorry

Oh no here-are (truncated) a few thing-diminutive-plural (truncated) sorry

(Oh no, there are a few things here, sorry)

Intersentential code-switching involves switching at sentential boundaries (MacSwan 1999:1), where one clause or sentence is in one language and the next clause or sentence is in the other, as in (2).

(2) I love Horlicks maar hier's niks

I love Horlicks but here-is (truncated) nothing

(I love Horlicks but there is nothing here)

Intrasentential code switching takes place within the clause boundary (Hamers \& Blanc 2000:260), such as in (3).

(3) Ek weet nie of daar iets down my throat was nie

I know not whether there something down my throat was not

(I don't know whether there was something down my throat)

The focus of the present study is on intrasentential code switching. This type of switching is problematic for syntactic theory in that the two languages are mixed within such circumscribed linguistic units as the clause or even the word, as in (4) below.

(4) We were bespreek-ing die onderwerp

We were discuss-past part the topic 
(We were discussing the topic)

\subsection{Related phenomena}

\subsubsection{Borrowing}

A distinction must be made between code switching and borrowing. Muysken (1995:189) refers to borrowing as "the incorporation of lexical elements from one language in the lexicon of another language". The key word here appears to be "incorporation", as it defines the moment when a previously code switched item becomes a borrowed item. According to Muysken (1995:190), three levels may be distinguished in the process. Initially, a fluent bilingual spontaneously inserts lexical element $l$ from language A into a sentence in language B. With time, the insertion of $l$ becomes a frequent occurrence in a speech community, i.e. so-called "conventionalised code switching" occurs (Muysken 1995:190). Finally, $l$ becomes adapted phonologically, morphologically and syntactically to the rules of language B and is fully integrated into the lexicon, being recognised as a word of language B by monolingual speakers. Short idiomatic expressions may be borrowed from one language into another in the same way as single words.

\subsubsection{Code mixing}

A second important distinction is that between code switching and what has commonly been referred to as "code mixing". Hamers \& Blanc (2000:260) define code mixing as a type of insertional code switching, where a constituent from language $\mathrm{A}$ is embedded into an utterance in language $\mathrm{B}$, where language $\mathrm{B}$ is clearly the dominant language. Inter- and intrasentential code switching, as defined and illustrated in (2) and (3) above, are examples of alternational code switching rather than insertional code switching, or code mixing. Such alternation involves properties of both languages (Hamers \& Blanc 2000:261), and so code 
switching requires that the bilingual has knowledge of the grammars of both languages concerned.

\subsubsection{Interference}

A third distinction is that between code switching and interference. Many definitions of interference, such as Haugen's (1956) "overlapping of two languages" (Grosjean 1984:299), do not make the distinction clear. Grosjean (1984:299) suggests that interference entails "the involuntary influence of one language on another". The point here is that code switching is a voluntary behaviour, over which the fluent bilingual has control, whereas interference occurs involuntarily, due to the influence of one language on the other. Grosjean (1984:299) suggests that such interference is particularly observable in conversations between a bilingual and a monolingual, where the bilingual is aware that code switching may impede communication. An example of this is interference at the phonological level, as in (5), where Afrikaans phonology affects the pronunciation of some English words.

(5) Fank you for de foot

(Thank you for the food)

An example of interference on the syntactic level (see (6) below), where word order in English is affected by that in Afrikaans, illustrates clearly the difference between interference and code switching as defined in this paper.

(6) I must the house clean

(I must clean the house)

If such an Afrikaans-English utterance involved code switching, one or more of the words would have been Afrikaans.

With this background on the concept of code switching, we may now turn to the central topic of this paper, namely the structural constraints on intrasentential code switching. 


\section{CONSTRAINTS ON INTRASENTENTIAL CODE SWITCHING}

\subsection{Background}

There have been various proposals of structural constraints regulating intrasentential code switching, with each proposing rules regarding where in a sentence a code switch may occur. Such proposals have typically been based on a study of a particular code switching corpus, and have later been tested against other corpuses, and found to be unable to account for the data. Besides failing empirical testing, the proposals have also been subject to much debate regarding their theoretical validity. Some of the more prominent theories will be briefly discussed below, providing a background against which the relevance of the present Minimalist approach to code switching may become clear.

Poplack (1980:585) proposed the Free Morpheme Constraint, which holds that codes may not be switched at a bound constituent, and the Equivalence Constraint, according to which codes will tend to be switched at points in the discourse where the syntactic rules of neither language are broken by the juxtaposition of the two codes (Poplack 1981:586), in other words, where the word-order of both languages remains intact. A theoretical problem with the proposal of these constraints as principles of the grammar (the grammar being the mental representation of the codes concerned) is the implication that there are rules specific to code switching. According to MacSwan (2000:38), this suggests that the interaction of the two grammars during code switching is ruled by a so-called "third grammar". The proposal of such a third grammar should be avoided unless forced by the data under analysis.

Both the Equivalence Constraint and the Free Morpheme Constraint have come under empirical scrutiny in various studies, and found to be inadequate in explaining cross-linguistic structural patterns in code switching data from various language pairs (cf. Kamwangamalu 1999:261, 263; MacSwan 1999:3). In the present study, the utterance in (4) above, repeated here as (7), was judged to be acceptable, although it disobeys the Free Morpheme Constraint, which does not allow a switch at a bound morpheme. 
(7) We were bespreek-ing die onderwerp

We were discuss-past part the topic

(We were discussing the topic)

Empirical evidence against the Equivalence Constraint was also gained in the present study, with the utterances in (8) and (9) below being judged to be unacceptable, while the Equivalence Constraint would not disallow them, as the surface word order of both languages remains intact.

(8) Hy sal go swim

(He will go swim)

(9) Die studente sal almal go play

(The students will all go play)

It may be concluded that, besides possessing inherent theoretical problems, the Free Morpheme Constraint and the Equivalence Constraint are not the operative principles governing code switching in these utterances. Both the theoretical and empirical validity of these constraints appear questionable.

Joshi (1985: 194) proposed the Constraint on Closed Class Items, according to which "closed class items cannot be switched". The theoretical problem with this constraint, as with those proposed by Poplack, is that the existence of special rules pertaining to a particular code switching corpus, or to code switching in general, defies the Minimalist trend toward a universal explanation for all linguistic phenomena. Muysken (1995:178), for example, states that "clearly we should aim for universal explanations when looking for grammatical constraints". Thus, the aim should be to provide a single account of both monolingual and bilingual phenomena.

The Constraint on Closed Class Items has also been found to fail empirical tests, such as that performed by MacSwan (1997:182-3). In the present study, the constraint fails to account for the recorded utterance in (10) below, where the closed class item is appears in Afrikaans 
between an English word thingy and an English phrase down your throat.

(10) Watse thingy is down your throat

What thing-diminutive is down your throat

(What thingy is down your throat)

It may be concluded that the Constraint on Closed Class Items cannot be the mechanism governing code switching here. Indications are that this constraint, like those of Poplack, lacks both theoretical and empirical validity.

Noting the importance of structural relations in code switching, Di Sciullo, Muysken and Singh (1986:6) proposed the Government Constraint, by which a governing element must be in the same language as its complement. This proposal comes closer than those previously mentioned to an independently motivated principle, based on government theory, rather than relying on resources external to the mixed language systems. Government, accordingly, is proposed to explain the grammaticality of both monolingual and bilingual utterances. However, a theoretical problem with this proposal is that, within the Minimalist Program, the government relation no longer plays a role. According to Cook \& Newson (1996:316), the notion of government is abandoned in the Minimalist approach, as its effects can be "reduced to more fundamental relations". The Government Constraint, then, becomes a code switching specific mechanism, and has the same theoretical shortcoming as the so-called "third grammar" approaches of Poplack and Joshi.

In addition to the problems with theoretical validity, the Government Constraint has also been found to fail empirical testing, such as that performed by MacSwan (1997:183). In the present study, data were gathered which cannot be accounted for by the Government Constraint. In the recorded utterance (11) below, the English complement a preschool teacher is governed by the Afrikaans complementiser as.

(11) Ek kan haar sien as a preschool teacher

I can her see as a preschool teacher

(I can see her as a preschool teacher) 
Furthermore, the utterance in (12) was judged to be acceptable, although the governing verb met is in English and the complement it governs die man van my drome is in Afrikaans.

(12) I just met die man van my drome.

I just met the man of my dream-plural

(I just met the man of my dreams)

It may be concluded that the Government Constraint is not the mechanism ruling code switching in these utterances. It would appear that the Government Constraint, too, lacks both theoretical and empirical validity.

Belazi, Rubin and Toribio (1994:228) based their Functional Head Constraint on Chomsky's (1993) assumption of f-selection as one of a group of feature checking processes, proposing that one of the features to be checked is language, i.e. which language is being spoken. According to the Functional Head Constraint (Belazi et. al. 1994:228), "the language feature of the complement f-selected by a functional head...must match the corresponding feature of that functional head." A theoretical problem with this proposal is that it appeals to a so-called "language feature", such as [+English] or [+Afrikaans] or [+Chinese], which has not been independently motivated to apply to any other linguistic phenomenon. Furthermore, the constraint has failed empirical testing (cf. MacSwan 1997:185). In the present study, the recorded utterance in (10), repeated here as (13), disobeys the Functional Head Constraint, as the functional head is is in Afrikaans and its complement down your throat is in English. Furthermore, the utterance in (14) was judged acceptable, even though the functional head that is in English and its complement ek sal saamgaan is in Afrikaans.

(13) Watse thingy is down your throat

What thing-diminutive is down your throat

(What thingy is down your throat)

(14) Who told you that ek sal saamgaan

Who told you that I will together-go (truncated)

(Who told you that I will go along) 
Clearly, the Functional Head Constraint cannot account for these data, and so it appears that the Functional Head Constraint lacks both theoretical and empirical validity. In an attempt to provide a more adequate account of code switching phenomena, we turn to a Minimalist approach below.

\subsection{The Minimalist approach to code switching}

It is evident from the above that the progression of proposals regarding the constraints on code switching has moved researchers gradually closer to a theory where the principles of code switching are not dependent on resources outside of the two grammars. The Minimalist approach to code switching renders all of the above-mentioned theories inadequate, because each makes some reference to rules specific either to code switching or to separate languages. Such rules are not acceptable within the Minimalist framework, where every language is considered to comprise a set of parameter values over a certain range of variation allowed by Universal Grammar (MacSwan 1999:10). The Minimalist approach aims to avoid such special rules and to create a system in which code switching can be explained in terms of the same principles as monolingual speech. The aim of Minimalism in code switching is to make the simplest assumptions possible (MacSwan 1999:2). In all of the previously mentioned proposals, some kind of control structure or "third grammar" was needed to mediate the interaction between the two grammars. A Minimalist approach to code switching makes the postulation of such a control structure unnecessary, as will be seen below.

In the Minimalist program, the language is assumed to consist of a computational system and a lexicon (Chomsky 1995:20). The assumption is that the computational system is fixed and invariant across languages, and that parameters are restricted to the lexicon. Hence, phrase structure is also invariant across languages at the initial level, and it is lexically based parameters which are responsible for varying phrase structure at the utterance level (cf. Van Gass, this issue). In other words, features of lexical items will determine whether the phrase is structured, for example, head-complement or complement-head. The idea that the lexicon is the seat of phrase structure leads to important implications for code switching. If the computational system is invariant across languages, and word order differences are attributable to lexically encoded features, then it can be assumed that the bilingual speaker has 
one computational system and, during code switching, is merely drawing items from two different lexicons. It is then the parametric values of the features encoded in these lexical items that are responsible for the syntactic features observed in code switching data. It is this idea that all parameters are, in fact, microparameters associated with individual lexical items that is important in code switching theory (MacSwan 1999:20).

According to Chomsky (1995), phrase structure is derived by the application of three operations, Select, Merge and Move, whose functions are constrained only in that lexically encoded features must match during the course of the derivation. The central role of the lexicon in syntactic processing is evidenced by Chomsky's (1995:20) suggestion that morphologically complex items are formed within the lexicon, before being picked by Select and entering the numeration. Derivational processes of morphology, therefore, apply within the lexicon. Movement is driven by feature checking, in that lexical items must move in order to have their features checked. Features to be checked include case, person, number and gender (MacSwan 2000:44). A derivation will crash if features are not checked, and will be cancelled if features mismatch, entailing that the utterance will either be corrected or will not be uttered. Within a Minimalist approach to code switching, then, the only code switched utterance that will be unacceptable is one in which features are not checked, in which the derivation has either crashed or been cancelled. Any code switched utterance whose features have been checked satisfies the requirements of the grammars involved. In this sense, it may be said that nothing constrains code switching except the grammars of the languages involved.

This is, indeed, what MacSwan proposes in his Minimalist approach to code switching. MacSwan's (1999:14) proposal is given in (15).

(15) Nothing constrains code switching apart from the requirements of the mixed grammars.

MacSwan (1999:19) claims that this assumption is Minimalist in two respects, namely that a strict interpretation of (15) relies on minimal theoretical assumptions, and that it relies, as far as possible, on the concepts and principles of the Minimalist program. 
In basic terms, (15) means that there is no merging of two grammars during code-switching. Rather, the bilingual speaker is making use of his fixed and invariant computational system, and drawing items from two different lexicons. The lexically specified features (such as case, gender, number and person) of these items must be checked in the same way as in monolingual speech (MacSwan 1999:22). This lexically based model has no need for a control structure or "third grammar", as had the previous non-lexicalist proposals regarding the constraints on code switching.

The assumption that "nothing constrains code switching apart form the requirements of the mixed grammars" (MacSwan 1999:14), is appealing from a Minimalist perspective. What remains to be seen is whether the assumption has sufficient descriptive adequacy, i.e. whether the code switching data of various language pairs can be accounted for in terms of the assumption. MacSwan (1997) assessed the empirical validity of the assumption on the basis of an extensive Spanish-Nahuatl corpus, and concluded that the assumption could account for the code switching phenomena observed. It is the aim of the present study to assess the empirical validity of the assumption on a limited sample of South African English-Afrikaans code switching data. For the purposes of this paper, the theory in (15) will be referred to as the "Minimalist assumption about code switching", or "Macs".

\section{RESEARCH DESIGN}

\subsection{Research question}

As is evident from (7-14) above, none of the previously proposed constraints provide an adequate account of South African English-Afrikaans code switching data. The aim of the present study is to determine the empirical validity of the Macs for South African EnglishAfrikaans code switching data. Specifically, an attempt will be made to answer the question in (16).

(16) Does the Macs provide an adequate account of South African EnglishAfrikaans code switching data? 


\subsection{Data collection procedures}

\subsubsection{Recorded data}

Data were gathered by means of audio tape recordings of two informal conversations among fluent English-Afrikaans bilinguals. The first recording took place at a coffee shop during conversation among three close friends, and the second at another coffee shop during conversation among four close friends.

In order to obtain an indication of the reliability of the researcher's transcription, all utterances in a ten minute sample of the first recording were orthographically transcribed by both the researcher and a colleague, a lecturer in linguistics experienced in orthographic transcription. The researcher's transcription was $97 \%$ accurate according to this exercise.

For the purposes of the present study, all utterances in which both English and Afrikaans occurred were transcribed. These utterances appear in Appendix A. The utterances were then grouped into cases of intersentential, extra sentential, and intrasentential code switching, and borrowing. The utterances in which intrasentential code switching occurred appear in Appendix B.

\subsubsection{Acceptability judgements}

(i) Data. A second set of data were generated for the purpose of obtaining acceptability judgements for code switched utterances. A total of 15 utterances was generated, and predictions made regarding their (un)acceptability to fluent English-Afrikaans bilinguals. The prediction of (un)acceptability was based on the researcher's intuitions regarding what is acceptable in a South African English-Afrikaans code switching context. The researcher is a fluent English-Afrikaans bilingual.

Seven of the generated utterances were aimed at refuting each of the five previously proposed constraints discussed above. In other words, an utterance was constructed to disobey a constraint, with the prediction that it would be judged acceptable, and so provide evidence that the constraint is not the rule governing code switching. In the case of the Equivalence 
Constraint, two utterances were constructed that would obey the constraint, with the prediction that they would be judged unacceptable, and so refute the constraint. The seven generated utterances, and the constraints they would refute if judged (un)acceptable as predicted, appear in Appendix C.

The remaining eight utterances were generated with the aim of testing the empirical validity of the Macs. Four of these utterances were predicted to be judged acceptable. In each of these four utterances, one feature was targeted. This feature was able to be checked during the derivation, and so a judgement of acceptability of the utterance would provide evidence in support of the Macs, that nothing constrains code switching apart from the requirements of the grammars involved, i.e. apart from the fact that every feature must be checked. The features targeted by the four utterances were case, number, gender and person. The remaining four utterances were constructed such that one of the aforementioned features could not be checked. These utterances were predicted to be judged unacceptable. Again, judgements that fulfilled the prediction of unacceptability would provide evidence to support the Macs. The eight generated utterances, and the features targeted by each, appear in Appendix D.

(ii) Consultants. There were two groups of consultants involved in the acceptability judgements. One group, the so-called "uneducated judges", consisted of 21 firstyear students taking General Linguistics at Stellenbosch University. All were fluent EnglishAfrikaans bilinguals, according to both their own and the researcher's opinion. These students had not been taught anything related to code switching.

The second group, the so-called "educated judges", consisted of two lecturers at the Department of General Linguistics at Stellenbosch University. Educated judge A, a fluent English-Afrikaans bilingual, has been studying syntax for 29 years, and Minimalism and code switching for 10 years. Educated judge B, a less fluent English-Afrikaans bilingual, has been studying syntax for 6 years, Minimalism for 3 years, and code switching for 2 years.

(iii) Procedure. The fifteen utterances were presented in the form of a questionnaire, which appears in Appendix E. Judges were asked to decide whether or not each utterance was acceptable if uttered during informal conversation between fluent 
bilinguals.

(iv) Acceptability judgements. The judges were instructed to base their judgements on their intuitions regarding the acceptability of the utterances in a specific situation, i.e. an informal conversation between two fluent Afrikaans-English bilinguals. They were instructed, both verbally and in the instructions on the questionnaire, to ignore the (un)grammaticality of the utterances, i.e. not to base their judgements on any prescriptive grammatical rules they had been taught. The aim was to gather judgements based on their linguistic competence, rather than judgements regarding the acceptability of the utterances according to prescriptive rules.

The use of intuitive judgements has a long history in linguistic research. Botha (1973:174) mentions the use of linguistic intuitions as empirical evidence against which predictions of linguistic hypotheses may be tested. The present study aimed to use the above intuitive judgements in this way. Botha (1981:228), however, warns against the use of so-called "spurious linguistic intuitions". Such spurious intuitions may be the result of non-linguistic factors inherent to the utterances to be judged or the context in which utterances are judged. Such non-linguistic factors may include perceptual complexity, articulatory complexity, and knowledge of the world. In the generation of the utterances to be judged, care was taken to avoid any such causes of spurious intuitions. It is assumed that the intuitive judgements reported in this study constitute an accurate reflection of the speakers' linguistic competence.

\section{RESULTS}

\subsection{Recorded data}

The utterances in Appendix A will be analysed one by one. The first utterance is given in (18). 
(18) Ja our car went in for a service yesterday and it's heeltemal heeltemal - wat's die woord wat ek soek - stukkend Yes our car went in for a service yesterday and it's completely completely what-is (truncated) the word that I search - broken (Yes our car went in for a service yesterday and it's completely completely what's the word I'm looking for - broken)

This utterance disobeys the Functional Head and Government Constraints, as well as the Constraint on Closed Class Items, as the truncated form of it is is in English, while the remainder of the sentence, its complement heeltemal heeltemal - wat's die woord wat ek soek - stukkend, is in Afrikaans. The utterance can, however, be accounted for by the Macs, as all features are checked, and thus the sentence obeys the requirements of both English and Afrikaans grammars.

The second utterance, in (19), has already been discussed as empirical evidence refuting both the Constraint on Closed Class Items and the Functional Head Constraint. This utterance can also be accounted for by the Macs, as all features are checked.

(19) Wat se thingy is down your throat

The third utterance, in (20), disobeys the Functional Head Constraint, as the Afrikaans pronoun iets, according to the DP hypothesis (Radford 1997:154), is a determiner. Its complement down my throat is in English. This utterance, too, can be accounted for by the Macs, as all features are checked.

(20) Ek weet nie of daar iets down my throat was nie.

The fourth utterance, in (21), disobeys the Government Constraint, as previously discussed, and also the Functional Head Constraint, as the functional head, the preposition as, is in Afrikaans and its complement a preschool teacher is in English. Once again, the Macs can account for the utterance, as all features are checked. 
(21) Ek kan haar sien as a preschool teacher.

It would appear that the Macs is able to account for every utterance in this small sample of South African English-Afrikaans intrasentential code switching.

\section{$5.2 \quad$ Acceptability judgements}

The results of the judging procedure appear in Table 1 in Appendix F. Evidence that refutes the Free Morpheme Constraint comes from utterance 14, judged acceptable, as predicted, by $100 \%$ of educated judges and $90 \%$ of uneducated judges. Utterance 1 also provides evidence that refutes the Free Morpheme Constraint, being judged acceptable, as predicted, by $100 \%$ of educated judges. The evidence to refute the Equivalence Constraint is less convincing, with $100 \%$ of the educated judges judging as predicted, but only $52 \%$ and $57 \%$ of uneducated judges judging as predicted for utterances 5 and 15, respectively.

As discussed above, evidence is also available to refute both the Government Constraint and the Functional Head Constraint. $100 \%$ of educated judges and $95 \%$ of uneducated judges

judged as predicted for utterance 4 , generated to refute the Government Constraint. Utterance 12, generated to refute the Functional Head Constraint, was judged as predicted by $100 \%$ of educated judges and $86 \%$ of uneducated judges.

Evidence to refute the Constraint on Closed Class Items is not clear from Table 1. Recall, however, the evidence in the recorded data that refutes this constraint.

With regard to the Macs, Table 1 reflects evidence that code switched utterances are acceptable if all features are checked, and unacceptable if features are not checked. Positive results in this regard were obtained for all four features targeted. With regard to case, utterance 6 was judged as predicted by $100 \%$ of educated and $71 \%$ of uneducated judges, while utterance 13 was judged as predicted by $100 \%$ and $81 \%$ of educated and uneducated judges, respectively. With regard to person, utterance 7 was judged as predicted by $100 \%$ and $86 \%$ of educated and uneducated judges, respectively. The results for utterance 3 , also generated to target person, are less convincing. However, it must be noted that utterance 3 
reflects a common error produced by Afrikaans mother tongue speakers of English, namely an error of concord, where the verb does not agree in number with the subject. It is possible that this feature need not be checked according to the grammatical rules associated with these lexical items in the lexicons of the speakers concerned. The number feature is not relevant in such a construction in Afrikaans, where only one verb form is used for both singular and plural subjects. With regard to number, utterance 2 was judged as predicted by $100 \%$ and $86 \%$ of educated and uneducated judges, respectively. The results for utterance 8 , also generated to target the feature number, are less convincing, and, once again, this could be a result of the specific language pair, namely English and Afrikaans. Finally, with regard to gender, utterances 9 and 11 were judged $100 \%$ as predicted by educated judges, and $86 \%$ and $90 \%$, respectively, by uneducated judges.

\section{DISCUSSION}

Due to the limited nature of the present study, with only a small amount of recorded data and judgements from limited numbers of both educated and uneducated judges, conclusions are tentative, and further research is necessary in order to gain support for or to refute any such conclusions. It would appear, however, that none of the previously proposed grammatical constraints on intrasentential code switching can account for the South African EnglishAfrikaans code switching data in the present study. Furthermore, it would appear that the Minimalist assumption regarding the constraints on code switching, given in (15) above, can account for the data in the present study. It would appear, therefore, that the Minimalist assumption, besides its theoretical validity within the Minimalist Program, has empirical validity for South African English-Afrikaans code switching data.

Further research in this area should aim to gather a more extensive corpus of South African English-Afrikaans code switching data. Furthermore, valid intuitive judgements of acceptability of generated utterances should be gathered from a larger number of both educated and uneducated judges, and such generated utterances should be structured to test more fully the Minimalist assumption of feature checking as the sole constraint on code switching. 


\section{REFERENCES}

Belazi, H.M., E.J. Rubin and A.J. Toribio. 1994. Code switching and X-bar theory: the functional head constraint. Linguistic Inquiry 25(2): 221-237.

Borer, H. 1984. Parametric syntax: case studies in Semitic and Romance languages. Dordrecht: Foris.

Botha, R.P. 1973. The justification of linguistic hypotheses. The Hague and Paris: Mouton.

Botha, R.P. 1981. The conduct of linguistic inquiry. The Hague, Paris and New York: Mouton.

Chomsky, N. 1995. The Minimalist program. Cambridge and London: MIT Press.

Cook, V. and M. Newson. 1996. Chomsky's universal grammar. An introduction (2 ${ }^{\text {nd }}$ ed.) Oxford and Cambridge: Blackwell Publishers.

Di Sciullo, A.M., P.Muysken and R. Singh. 1986. Government and code-mixing. Journal of linguistics 22: 1-24.

Grosjean, F. 1984. Life with two languages: an introduction to bilingualism. Cambridge: CUP.

Hamers, J.F. and H.A. Blanc. 2000. Bilinguality and bilingualism. Cambridge: CUP.

Hoffmann, C. 1991. An introduction to bilingualism. London: Longman.

Kamwangamalu, N.M. 1999. The state of codeswitching research at the dawn of the new millenium (1): focus on the global context. South African Journal of Linguistics 17(4): 256-277.

MacSwan, J. 1997. A Minimalist approach to intrasentential code switching: SpanishNahuatl bilingualism in Central Mexico. PhD dissertation: UCLA.

MacSwan, J. 1999. A Minimalist approach to intrasentential code switching. Paper presented at the Second International Symposium on Bilingualism, Newcastle upon Tyne.

MacSwan, J. 2000. The architecture of the bilingual language faculty: evidence form intrasentential code switching. Bilingualism 3(1): 37-54.

Muysken, P. 1995. Code-switching and grammatical theory. In L. Milroy and P. Muysken (eds.) 1995. One speaker, two languages: 177-197. Cambridge: CUP.

Poplack, S. 1980. Sometimes I'll start a sentence in English y termino en Español: toward a typology of code-switching. Linguistics 18: 581-618. 
Radford, A. 1997. Syntactic theory and the structure of English. A minimalist approach. Cambridge: CUP. 


\section{APPENDIX A: UTTERANCES CONTAINING BOTH ENGLISH AND AFRIKAANS}

1. I'm not sure maar ek love cheesecake

2. Nee as ek kaaskoek gaan ek nie hot chocolate nie.

3. I love Horlicks maar hier's niks.

4. I think ek gaan nou eers net tee drink.

5. Dis baie cheap.

6. Maar ek wil healthy iets eet.

7. Nee ek sal nou-nou gaan dis fine.

8. Nee lemon tee.

9. Dit is lemon tee.

10. Dis groot ronde ringe chips.

11. Jy's altyd daar as daar free goed is.

12. O nee hier's 'n paar goedjies, sorry.

13. Dis cool.

14. Ja maar dis cool.

15. Not really maar jy kan maar.

16. Honey ja maar hulle sal nie heuning hê nie.

17. And then there's cottage pie, bobotie, verder kan ek nie sien nie.

18. I shouldn't ja nou moet ek maar gesonde goedjies eet.

19. Did I tell you that uhm he had a seksievergadering like a vloervergadering

20. He didn't even call him the guy from the H.K. (Afrikaans pronunciation), he just told me the H.K. (Afrikaans pronunciation) said.

21. No it's the H.K. (Afrikaans pronunciation) of his vloer.

22. O ek love cheesecake.

23. Ek love chocolate koek.

24. O, nee ek love dit.

25. We're gonna start with uhm Mariaan het gister gesê something of grain or grain of wheat.

26. Of is dit nou die grass ene?

27. Ek weet nie dis net vir my soos elke keer 'n effort om klas toe te gaan.

28. Seker maar die chips wat lank vat. 
29. Dit is nie ' $\mathrm{n}$ fasting nie dit is starvation.

30. Ek het so 'n boek gelees van fasting of allerhande goed maar dan praat hulle ook van fasting.

31. Maar uhm toe ek kyk na die appropriations daarso wat hy voorbeelde gegee het van hoe hy dit gaan opdeel by Henry the fifth het hy mos iets gesê [INTERRUPTION] van die mythmaking.

32. En toe is ek heel met daai term so [NOISE] dat ek dink ek moet net die myth-making en die ideal ruler myth-making dit bespreek meantime weet ek baie meer van die ander goed van die Catholics te compare maar ek het dit nie gesê nie.

33. Ek dink dit was 'n bargain.

34. So then I can use the other two thousand to fix the rust then it's perfect dan's daar nie roes.

35. Ja our car went in for a service yesterday and it's heeltemal heeltemal [NOISE] wat's die woord wat ek soek opgemors.

36. Want die ou sê my pa kan maar amper 'n nuwe kar koop want dit gaan baie kos om dit reg te maak 'cos the the the the the the, die stuur... die stuur something something is... want Anel sê toe as sy ry dan voel sy die kar gaan so.

37. Sy alignment is nie lekker nie en toe sê hy want as 'n mens in die sypaadjie vasry en jou wiele wil draai maar jy kan nie draai nie dan mors dit jou thingy op.

38. Dis 'n groot groot motorbike.

39. Was dit nie jy op die bike?

40. En toe het ek balans oor die bike verloor.

41. Maar die bike het niks oorgekom nie.

42. Wat worry jy oor die bike?

43. Maar ek is fine né.

44. Ek kry die gevoel almal sê net deesdae ja daar's niks fout nie bye next.

45. My pa's net 'n G.P. (English pronunciation).

46. Dit was so half 'n snaakse case.

47. Maar dit het nie gewys op die X-rays nie.

48. Hy't vir my deur CAT scans en ek weet nie wat alles gesit nie.

49. Dis baie cool.

50. Daar was klomp audience. 
51. Dit gaan so om en so om en alles aparte verskillende angles.

52. Jy lyk troubled.

53. Dit is so cool.

54. Wat se thingy is down your throat?

55. Ek weet nie of daar iets down my throat was nie.

56. Toe kan ek nie slaap nie en ek voel terrible.

57. Ek voel heel dizzy.

58. Want avo's en olywe is mos die enigstes wat ...olie ...vet in het.

59. O ek love peppermints.

60. Sorry dis al wat ek kon kry

61. Kom ons gaan betaal daar dan's dit makliker I think.

62. Moenie worry nie.

63. Ja maar jy't okay geskryf.

64. Ek het laas ook 'n front page toe besluit ek nie hierdie keer nie.

65. Dit is 'n waste.

66. Toe my ma-hulle hier was was dit soos 'n huge thing en hulle't ge-sing songs en ek weet nie wat alles nie but now it's totally different.

67. And De Vos went ja ek dink hulle hou van jou.

68. Ek gaan nou op 'n 'n major vas.

69. Nee dis 'n starve.

70. Ek kan haar sien as a preschool teacher.

71. She just thought "poppie".

72. Fur dashboard miskien.

73. Sy't dit nog nooit geknip vandat sy gebore is and she's like Standard Four.

74. Sy's seker maar jealous.

75. Sy't nog nooit haar hare geknip since she's born.

76. Hy praat net so vaguely.

77. Ek het dit ge-love.

78. Maar net as ons na 'n cool plek gegaan het ja.

79. Die cool-ste was as ons melkery toe gegaan het dan het jy drinking yoghurt gekry.

80. Dit gaan my beter doen as om nou daar te sit en nogsteeds'n bietjie lost wees. 
81. Ek wil vir my een van daai klein daai klein wat jy die klein tape-ies insit wou ek vir my vir Sielkunde wil ek dit gaan tape het.

82. Nee dit gaan freaking erg wees né.

83. You go to the LWSK (Afrikaans pronunciation) and you say this is this is the story.

84. Weet jy wat? Ons kan al if if everything goes according to plan we'll all graduate on the $10^{\text {th }}$ of December.

85. Hy kan nie so emotionally betrokke raak nie. 


\section{APPENDIX B: UTTERANCES CONTAINING INTRASENTENTIAL CODE SWITCHING}

1. Ja our car went in for a service yesterday and it's heeltemal heeltemal ... wat's die woord wat ek soek ... opgemors.

2. Wat se thingy is down your throat?

3. Ek weet nie of daar iets down my throat was nie.

4. Ek kan haar sien as a preschool teacher. 
APPENDIX C: UTTERANCES GENERATED TO REFUTE CONSTRAINTS

\section{Utterance}

1. Sy het haar fiets ge-ride to the park.

2. I just met die man van my drome.

3. Hy sal go swim.

4. Wat se plante are onder in die tuin?

5. Who told you that ek sal saamgaan?

6. We were bespreek-ing die onderwerp.

7. Die studente sal almal go play.

\section{Prediction}

acceptable

acceptable

unacceptable

acceptable

acceptable

acceptable

unacceptable

\section{Constraint}

Free Morpheme

Government

Equivalence

Closed Class Items

Functional Head

Free Morpheme

Equivalence 


\section{APPENDIX D: UTTERANCES GENERATED TO SUPPORT Macs}

\section{Utterance}

1. The instructor said all die hond moet saam hardloop.

2. Daardie ou play hockey for Maties.

3. He's looking for sy eie skoene.

4. Die meisie in my koshuis flies with SAA.

5. I wish all die mense wil my net uitlos.

6. Sy sê he must go to the doctor.

7. She wants sy eie kamer.

8. Sy wil hê him must come.

\section{Prediction}

unacceptable

unacceptable

acceptable

acceptable

acceptable

acceptable

unacceptable

unacceptable
Feature

number

person

case

person

number

gender

gender

case 


\section{APPENDIX E: QUESTIONNAIRE}

\section{KODEWISSELING AANVAARBAARHEIDSVRAELYS \\ CODE SWITCHING ACCEPTABILITY QUESTIONNAIRE}

Kodewisseling is ' $\mathrm{n}$ spraakstyl waarin vlot tweetalige sprekers van een taal na 'n ander en terug beweeg (MacSwan 2000:38). Met hierdie vraelys word gepoog om die aanvaarbaarheid van kodewisselinguitinge te bepaal. Die doel is om oordele te versamel oor hierdie uitinge se aanvaarbaarheid vir vlot tweetaliges. Die grammatikaliteit van die uitinge, of hulle aanvaarbaarheid volgens preskriptiewe reëls, is nie hier ter sake nie.

Beoordeel die aanvaarbaarheid van die onderstaande uitinge met die aanname dat hulle gebruik is tydens informele gesprekke tussen twee vlot Afrikaans-Engels tweetaliges wat mekaar goed ken. Merk telkens 'n aanvaarbare uiting met ' $n \checkmark$ en 'n onaanvaarbare uiting met 'n $X$.

"Code switching is a speech style in which fluent bilinguals move in and out of two (or more) languages." (MacSwan 2000:38) This questionnaire is intended to determine the acceptability of code switched utterances. The aim is to gather judgements of fluent bilinguals regarding the acceptability of the utterances. The grammaticality of the utterances, or their acceptability according to prescriptive rules, is not at issue here.

Evaluate the acceptability of the utterances below with the assumption that they were uttered during informal conversations between two fluent Afrikaans-English bilinguals who know each other well. Mark acceptable utterances with $a \checkmark$ and unacceptable utterances with a $\mathrm{X}$.

1. Sy het haar fiets ge-ride to the park.

2. The instructor said all die hond moet saam hardloop.

3. Daardie ou play hockey for Maties.

4. I just met die man van my drome.

5. Hy sal go swim.

6. He's looking for sy eie skoene.

7. Die meisie in my koshuis flies with SAA.

8. I wish all die mense wil my net uitlos.

9. Sy sê he must go to the doctor.

10. Wat se plante are onder in die tuin?

11. She wants sy eie kamer.

12. Who told you that ek sal saamgaan?

13. Sy wil hê him must come.

14. We were bespreek-ing die onderwerp.

15. Die studente sal almal go play. 
APPENDIX F: TABLE 1. RESULTS OF JUDGING PROCEDURE

\begin{tabular}{|c|c|c|c|c|c|c|}
\hline \multirow[t]{3}{*}{ UTTERANCE } & \multirow[t]{3}{*}{ PREDICTION } & \multicolumn{4}{|c|}{ RESULTS } & \multirow{3}{*}{$\begin{array}{c}\text { CONSTRAINT / } \\
\text { FEATURE } \\
\text { TARGETED }\end{array}$} \\
\hline & & \multicolumn{2}{|c|}{$\begin{array}{l}\text { prediction met: } \\
\text { support Macs, } \\
\text { refute other }\end{array}$} & \multicolumn{2}{|c|}{$\begin{array}{l}\text { prediction not met: } \\
\text { refute Macs, } \\
\text { support other }\end{array}$} & \\
\hline & & $\%$ uneducated & $\%$ educated & $\%$ uneducated & \%educated & \\
\hline 1 & acceptable & 52 & 100 & 48 & 0 & Free Morpheme \\
\hline 2 & unacceptable & 86 & 100 & 14 & 0 & number \\
\hline 3 & unacceptable & 24 & 50 & 76 & 50 & person \\
\hline 4 & acceptable & 95 & 100 & 5 & 0 & Government \\
\hline 5 & unacceptable & 52 & 100 & 48 & 0 & Equivalence \\
\hline 6 & acceptable & 71 & 100 & 29 & 0 & case \\
\hline 7 & acceptable & 86 & 100 & 14 & 0 & person \\
\hline 8 & acceptable & 62 & 50 & 38 & 50 & number \\
\hline 9 & acceptable & 86 & 100 & 14 & 0 & gender \\
\hline 10 & acceptable & 62 & 50 & 38 & 50 & Closed Class \\
\hline 11 & unacceptable & 90 & 100 & 10 & 0 & gender \\
\hline 12 & acceptable & 86 & 100 & 14 & 0 & Functional Head \\
\hline 13 & unacceptable & 81 & 100 & 19 & 0 & case \\
\hline 14 & acceptable & 90 & 100 & 10 & 0 & Free Morpheme \\
\hline 15 & unacceptable & 57 & 100 & 43 & 0 & Equivalence \\
\hline
\end{tabular}

